Yuzuncu Y1l University
Journal of the Institute of Natural \& Applied Sciences

Research Article

\title{
Germination and Seedling Growth of Some Turfgrass Species Exposed to Smoke Solutions
}

\author{
Ahmet OZBEK ${ }^{1}$, Ugur BASARAN ${ }^{1}$, Medine COPUR DOGRUSOZ ${ }^{* 1}$ \\ ${ }^{1}$ Yozgat Bozok University, Agriculture of Faculty, Field Crops,, 66200, Yozgat, Turkey \\ Ahmet OZBEK, ORCID No:0000-0002-0875-9973, Ugur BASARAN, ORCID No:0000-0002-6644-5892, \\ Medine COPUR DOGRUSOZ, ORCID No:0000-0002-9159-1699 \\ *Corresponding author e-mail: medine.copur@bozok.edu.tr
}

\section{Article Info}

Received: 05.05.2021

Accepted: 13.10 .2021

Online December 2021

DOI:10.53433/yyufbed.932611

\section{Keywords}

Turfgrass species,

Smoke solution,

Germination,

Seedling

\begin{abstract}
This study aimed to investigate the effect of priming with plantderived smoke solutions (SS) on the germination, seedling growth and chemical content of three turfgrass species (Lolium perenne, Festuca arundinacea, Poa pratensis). SS was applied at six concentrations $(0,0.5,1,5,10$ and $20 \%)$ in petri and pot conditions. In petri condition, SS did not stimulate the germination speed, and the highest concentrations (20\%) led to lower values than control. In the pot conditions, seedling growth and chemical content were significantly stimulated by the SS. The effect of the SS varied depending on the species and concentrations. Shoot and root length in grass species were improved by the SS, except in $P$. pratensis for shoot length. Compared to control, higher shoot dry weight in $F$. arundinacea $(1 \%)$ and higher root dry weight in L. perenne $(5 \%)$ and $F$. arundinacea $(0.5 \%)$ were determined at certain concentrations. These results showed that priming with SS at appropriate concentrations may lead to healthy and vigorous seedlings. When seedling vigor and visuality are evaluated together, it has been determined that priming with low concentrations of SS such as 0.5 and $1 \%$ can produce vigorous seedling.
\end{abstract}

\section{Duman Solüsyonlarına Maruz Kalan Bazı Çim Türlerinin Çimlenme ve Fide Büyümesi}

\section{Makale Bilgileri}

Geliş: 05.05.2021

Kabul: 13.10 .2021

Online Aralık 2021

DOI: 10.53433/yyufbed.932611

\section{Anahtar Kelimeler}

Çim türleri,

Duman solüsyonu,

Çimlenme,

Fide gelişimi
Öz: Bu çalışmada, bitki kaynaklı duman solüsyonları ile priming uygulamasının üç farklı çim türünde (Lolium perenne, Festuca arundinacea ve Poa pratensis) çimlenme, fide büyümesi ve kimyasal içeriği üzerindeki etkisinin araştırılması amaçlanmıştır. Duman solüsyonları petri ve saksı koşullarında altı konsantrasyonda (\%0, 0.5, 1, 5, 10 ve 20$)$ uygulanmıştır. Petri koşulunda, duman solüsyonları çimlenme hızını teşvik etmemiş ve en yüksek konsantrasyonlar (\%20) kontrolden daha düşük değerlere yol açmıştır. Saksı koşullarında ise fide büyümesi ve kimyasal içerik duman solüsyonları tarafından önemli ölçüde teşvik edilmiştir. Duman solüsyonunun olumlu etkisi türe ve konsantrasyonlara bağlı olarak değişiklik göstermiştir. $P$. pratensis' nin sürgün uzunluğu hariç tüm türlerde sürgün ve kök uzunluğu duman solüsyonları tarafindan pozitif yönde etkilenmiştir. Kontrol ile karşılaştırıldığında, belirli konsantrasyonlarda $F$. arundinacea' da daha yüksek sürgün $(\% 1)$ ve kök kuru ağırlığı $(\% 0.5)$ ve $L$. perenne' de daha yüksek kök kuru ağırlığı (\%5) belirlenmiştir. Bu sonuçlar, uygun konsantrasyonlarda bitkisel kaynaklı duman solüsyonları ile priming uygulamasının çim türlerinde sağlıklı ve kuvvetli fideler oluşturulabileceğini göstermiştir. Fide canlılığı ve görselliği birlikte değerlendirildiğinde $\% 0.5$ ve 1 gibi düşük solüsyon konsantrasyonları ile priming işleminin daha güçlü fideler sağlayabileceği tespit edilmiştir. 


\section{Introduction}

Fire and smoke are essential or effective factors for germination in some plants (Crosti et al., 2006). These effects are particularly evident in seeds that respond to the physical (i.e. temperature and light) or chemical (smoke, gas, nutrients) germination cues associated with fire. Seeds of many species germinate in stimulate the embryo directly or in response to physical signals associated with fire, such as fracturing or desiccation of the seed coat by heat (Jeffrey et al., 1998). Many plant species particularly grasses rapidly germinate after the rain that followed the bush fires, indicating that plantderived smoke contains some bioactive metabolites that are responsible for stimulating seed germination (Gupta et al., 2020). This is may be associated with physical and chemical results of fire. Both smoke and smoke-water include chemical stimulants that are active on germination (Van Staden et al., 2000). High number of the species from different families responded positively to smoke with significantly higher seed germination (Dixon et al., 1995; Baskin \& Baskin, 1998). Stimulating effect of smoke on seed germination and seedling growth of some economically important agricultural and horticultural crops (Sparg et al., 2006; Ghebrehiwot et al., 2009; Kulkarni et al., 2011; Basaran et al., 2019) indicated that plant-derived smoke and aqueous extracts could be useful practices in the wide field of agriculture to improve growth and yield (Elsadek \& Yousef, 2019).

Turfgrasses are commonly propagated by seeds. In some genera of turfgrasses, the presence of low germination percentage and poor seedling vigor are the main problem in seed propagation (Salehi \& Khosh-Khui, 2005; Richardson \& Hignight, 2010). A poor seedling emergence leads to a poor turfgrass stand, and weed infestations (Shiade \& Boelt, 2020) results waste of time and resources. It is very important, particularly under sub-optimal conditions, to reduce the period between sowing and seedling emergence in turfgrass (Krol et al., 2014).

Plant-derived smoke provided an important germination signal for a number of Poaceae species (Ghebrehiwot et al., 2009) widely studied in Australian native grasslands for its effect in seed germination and seedling growth (Dixon et al., 1995; Read \& Bellairs, 1999; Clarke \& French, 2005), and results showed the effect of smoke on grass species was highly variable. Besides these different results on different grass species, there is little information about smoke solution effects on turfgrass.

The objective of this study was to investigate the effects of smoke solutions on seed germination and seedling growth of widely cultivated turfgrass species such as Lolium perenne, Festuca arundinacea and Poa pratensis.

\section{Materials and Methods}

In this study, local commercial seeds of Lolium perenne (Lp), Festuca arundinacea $(\mathrm{Fa})$ and Poa pratensis $(\mathrm{Pp})$ were used as the plant material. Germination and seedling growth parameters were determined under fully controlled climate room conditions at the Agriculture Faculty of Yozgat Bozok University. Smoke-water was produced by burning $5 \mathrm{~kg}$ of wheat straw using a special mechanism (furnace, vacuum machine and large jar), and smoke generated was passed through a glass column containing $5000 \mathrm{~mL}$ of tap water until the burning is complete (Basaran et al., 2019). The solution was then filtered with filter papers and used as the stock solution. For different concentration, stock solution was diluted with distilled water. Germination tests were performed separately in petri and pot conditions.

\subsection{Petri experiment}

The seeds of each species were primed in different concentrations $(0 \%, 0.1 \%, 0.5 \%, 1 \%, 5 \%$, $10 \%, 20 \%)$ of smoke solution for 18 hours at room conditions $\left(20 \pm 2{ }^{\circ} \mathrm{C}\right)$. Then seeds were placed in 90 mm petri dishes on filter paper as 25 seeds for $L p$ and $F a$ and 50 seeds for $P p$ with three replications. After $3 \mathrm{ml}$ distillate water added, petri dishes were isolated with parafilm and incubated at a constant temperature $\left(22{ }^{\circ} \mathrm{C}\right)$ under 16:8 $\mathrm{h}$ light/dark photoperiod. Germination characteristics of the species were collected different times due to genetically different germination habits; for $L p, F a$ and $P p$ on day 8,19 and 26 respectively. Seeds with a radicle length of $\geq 2 \mathrm{~mm}$ were considered germinated. 
Germination percentage (1) and speed (2) were determined with the following formulas:

$$
\begin{gathered}
\text { Germination percentage }(G P)=\frac{\text { Number of total germinated seeds }}{\text { Total number of seeds tested }} \times 100 \\
\text { Germination speed }(G S)=\frac{\text { Number of germinated seeds }}{\text { Day of first count }}+\cdots+\frac{\text { Number of germinated seeds }}{\text { Day of final count }}
\end{gathered}
$$

\subsection{Pot experiment}

The pots $(30 \times 40 \times 7 \mathrm{~cm})$ were filled with same soil to $4 \mathrm{~cm}$ height. Seed norm for pots were $30 \mathrm{~g} \mathrm{~m}^{-2}$ in $L p$ and $F a$, and $15 \mathrm{~g} \mathrm{~m}^{-2}$ in $P p$. After sowing the seeds were covered with approximately 1 $\mathrm{cm}$ of soil and irrigated with the concentrations $(0.5 \%, 1 \%, 5 \%, 10 \%$ and $20 \%)$ of smoke solutions up to field capacity and also with tap water $(0 \%)$ as control. All the treatments were repeated three times, resulting in a total of fifty-four pots. Then pots were taken into the climate room at $22{ }^{\circ} \mathrm{C}$ and $16: 8$ hour light/dark photoperiod. Subsequent irrigation was done with tap water.. In pot experiment, shoot length, root length, shoot dry weight, root dry weight, crude protein and mineral content of shoots were determined. These parameters were collected 21, 28 and 34 days after sowing in $L p, F a$ and $P p$ respectively.

Dry weight was determined separately in shoot and root samples. To determine the dry weight, samples were weighted and then dried to constant weight at $70{ }^{\circ} \mathrm{C}$ (Chumpookam et al., 2012). Crude protein and mineral content was determined only in shoot samples by using near infrared reflectance spectroscopy (Foss 6500) (Foss NIRSystems, Inc., Silver Spring, MD, USA) with IC0904FE software.

All the data were subjected to SPSS 20.00 analysis and the differences between the means were determined using Duncan's multiple comparison tests, separately for each species.

\section{Results}

\subsection{Petri experiment}

In the petri experiment, the effect of smoke solutions (SS) on germination speed was significant $(p \leq 0.01)$. The percentage of germination in turfgrass also differed significantly $(p \leq 0.01)$ amongst the treatments (Figure 1). However, SS treatments did not provide any improvement compared to control both in germination speed and percentage and even resulted with lower values, especially at the highest SS doses (20\%).
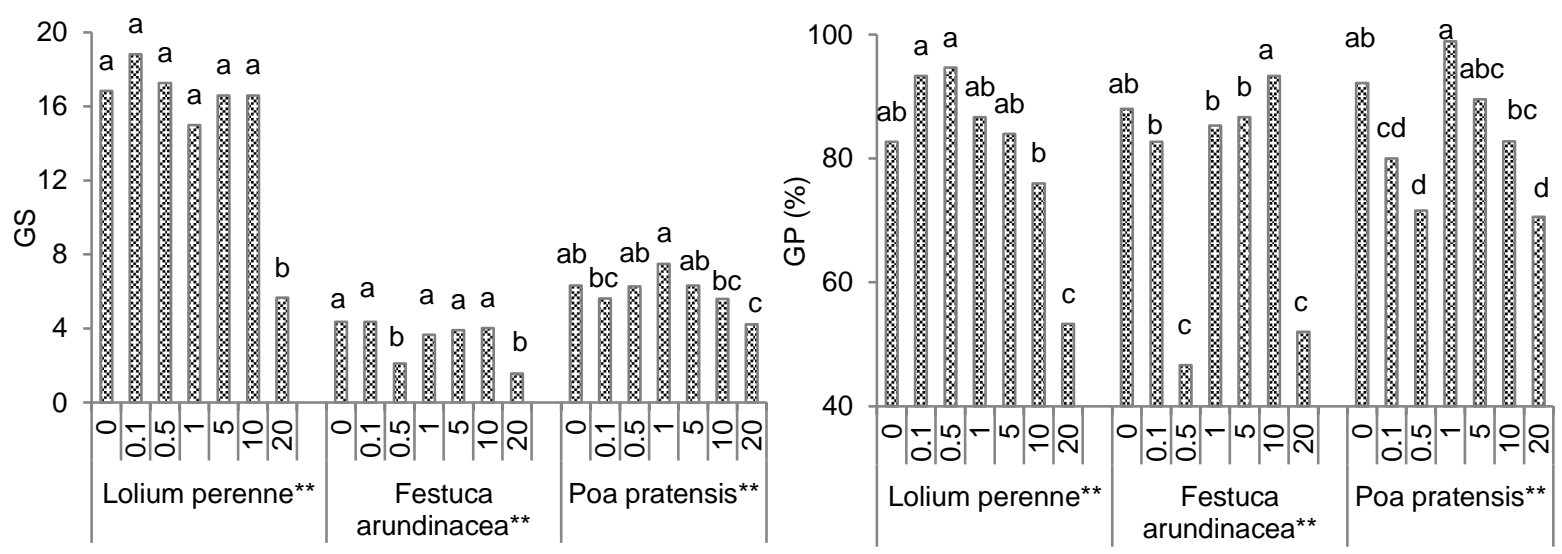

Figure 1. The main effect of priming with smoke solution in different concentrations (\%) on germination speed (GS) and germination percentage (GP) in the studied turfgrasses in petri condition $(* *: p \leq 0.01)$. 


\subsection{Pot experiment}

In pot condition, the effect of the concentrations of SS on the shoot and root length of grass species was evaluated (Figure 2). The effect of SS on grass species was different (Figure 3). The shoot length was significantly $(\mathrm{p} \leq 0.01)$ altered in $F a$ and $P p$ by SS. Shoot length promoted by SS and was higher than control in $\mathrm{Fa}$ at all the concentrations. Contrarily, shoot length decreased in $P p$ under all the concentrations of SS. The effect of SS on root length was significant $(\mathrm{p} \leq 0.01)$ and positive in $L p$. The lowest root length of $L p(10.17 \mathrm{~cm})$ was measured in control treatment. Root length of $F a$ and $P p$ were found to be insignificant among the treatments.
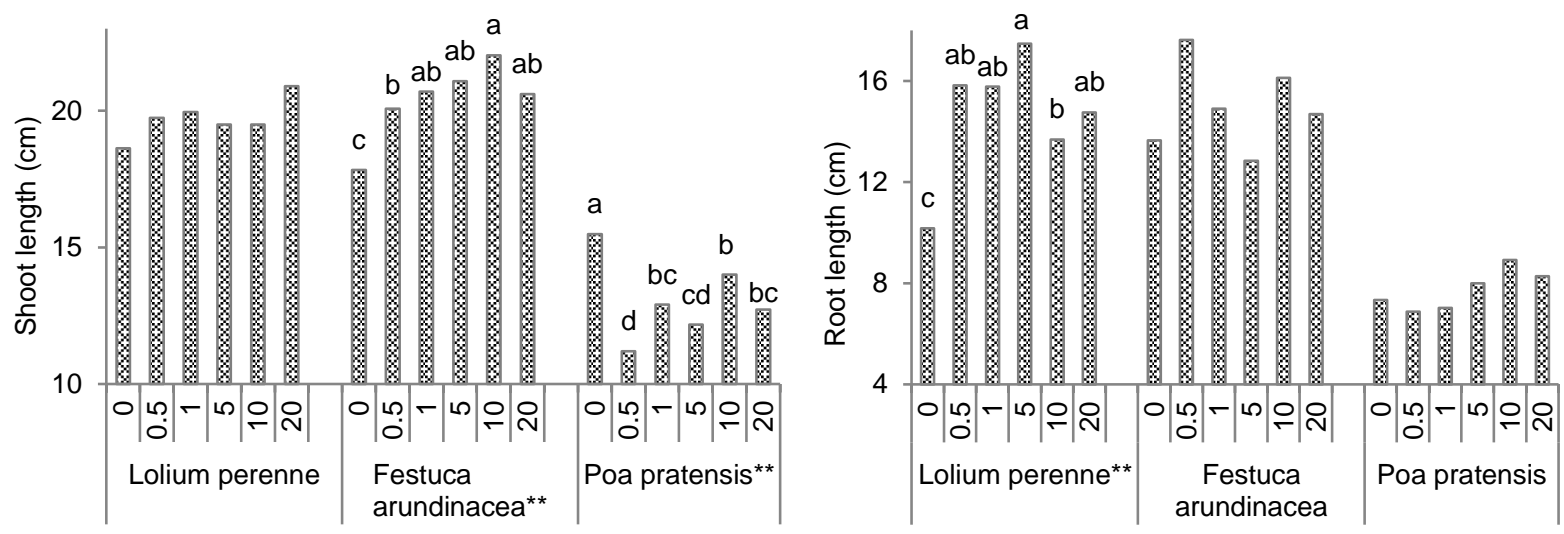

Figure 2. The main effect of smoke solution concentrations (\%) on shoot length and root length in the studied turfgrasses in pot condition $(* *: p \leq 0.01)$. 


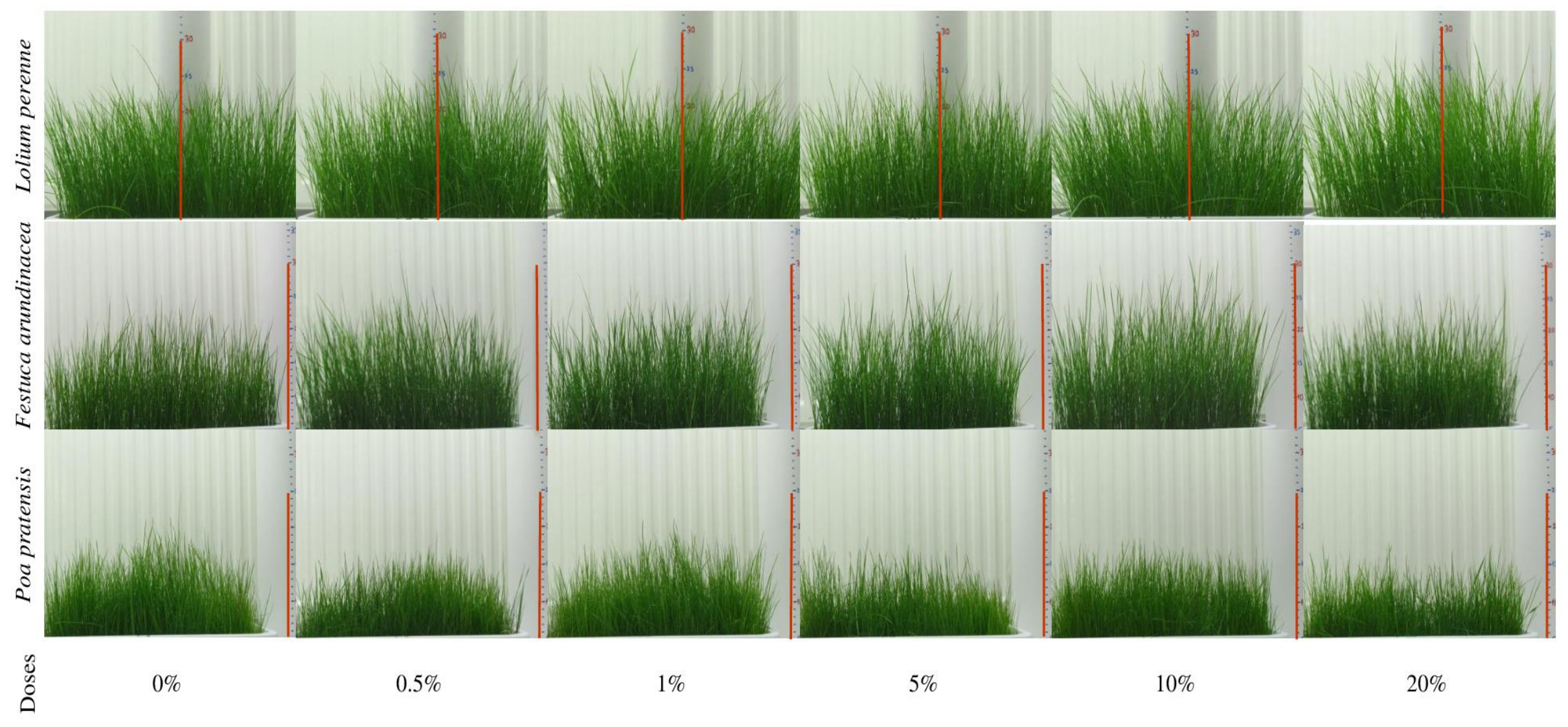

Figure 3. The view of turfgrasses on harvest time at different concentrations of smoke solution. Harvest times: 21 DAS for Lolium perenne, 28 DAS for Festuca arundinacea and 34 DAS for Poa pratensis. (DAS: days after sowing) 
The effect of the treatments on shoot dry weight was significant ( $\mathrm{p} \leq 0.01)$ in the $F a$ and $P p$. (Figure 4). The highest shoot dry weight of $F a$ was determined at 1\% of SS. But, shoot dry weight of $P p$ was statistically not above control at any SS dose. The highest concentration (20\%) resulted in a significant reduction in shoot dry weight in both $F a$ and $P p$ compared to control. This result indicates that solution concentration is crucial and has a species-specific effect. In terms of root dry weight, significant $(\mathrm{p} \leq 0.01)$ variation was observed among to treatments in the three turfgrass species (Figure 4). Doses of 5\% in $L p$ and of $0.5 \%$ in $F a$ showed higher root dry weight than control, but other concentrations were lower than control. Root dry weight in $P p$ was adversely affected by SS, with lower values than control at all concentrations.
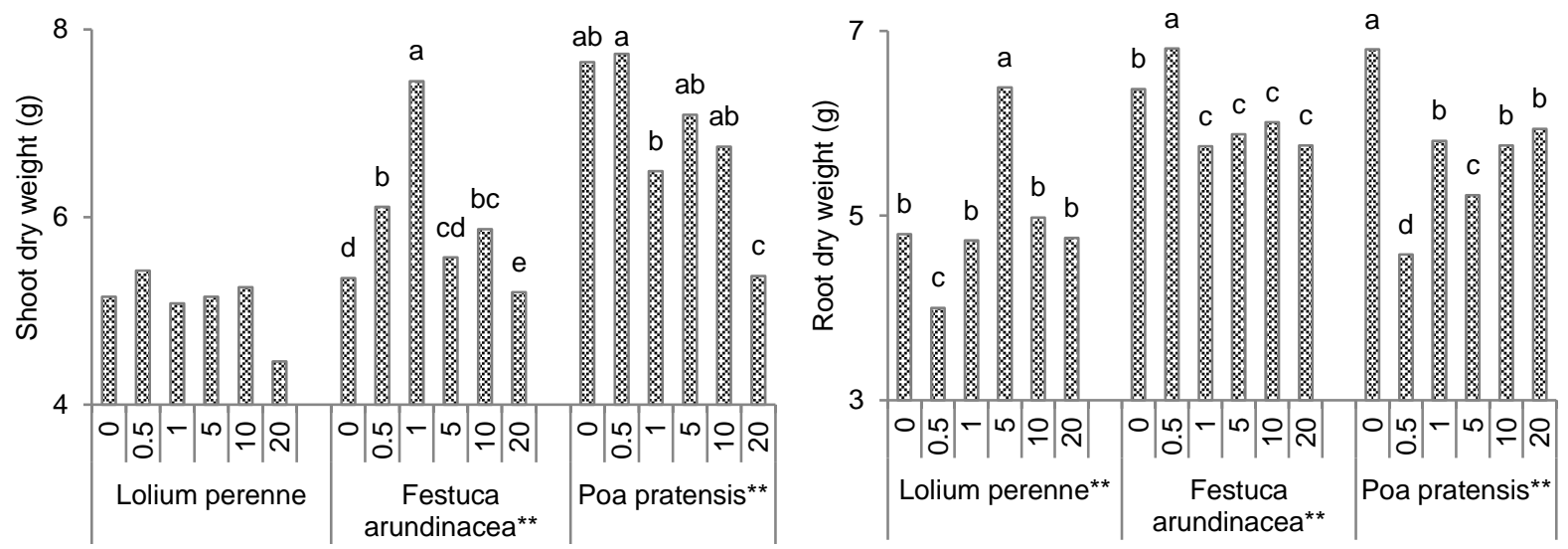

Figure 4. The main effect of smoke solution concentrations (\%) on shoot and root dry weight (g) in the studied turfgrasses in pot condition $(* *: p \leq 0.01)$.

The species-specific effect of SS concentrations was also evident in protein content. In terms of crude protein content in shoot, SS showed no significant change in $L p$, however, was significant in $F a(\mathrm{p} \leq 0.01)$ and $P p(\mathrm{p} \leq 0.05)$. All the treatments in $F a$ and $P p$ were of higher values than control, except for $P p$ at 5\% (Figure 5). The maximum protein content was detected at concentrations of 5\% (20.28\%) and 20\% (20.43\%) in Fa and at 20\% (18.86\%) in Pp.

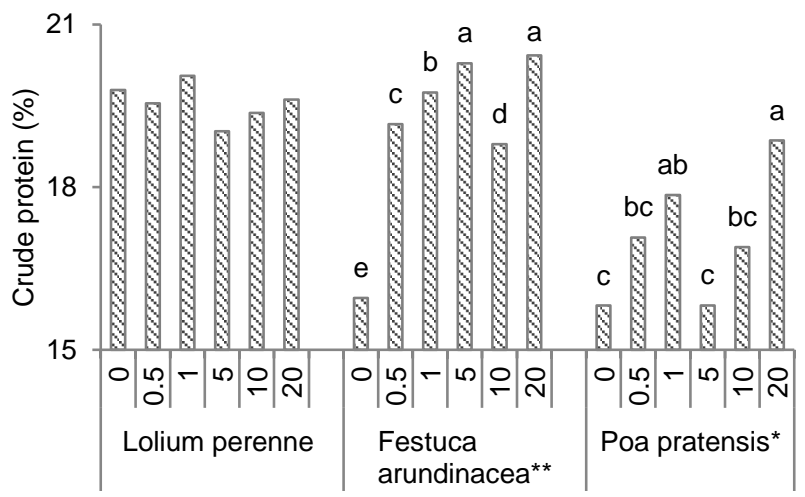

Figure 5. The main effect of smoke solution concentrations (\%) on crude protein content (\%) of shoot in the studied turfgrasses in pot condition $(* *: p \leq 0.05, p \leq 0.01)$.

The results also showed that $\mathrm{SS}$ altered the mineral $(\mathrm{Ca}, \mathrm{Mg}, \mathrm{P}$ and $\mathrm{P})$ uptake of the turf grasses studied (Figure 6). In terms of P content, the effect of SS was significant in $L p(\mathrm{p} \leq 0.05)$ and $F a(\mathrm{p} \leq 0.01)$, but not in $P p$. It enhanced $\mathrm{P}$ uptake in $L p$ only at the highest concentration $(20 \%)$ and other concentrations were similar to control. With SS treatments, except $1 \%, \mathrm{P}$ content was higher than control in $\mathrm{Fa}$. 

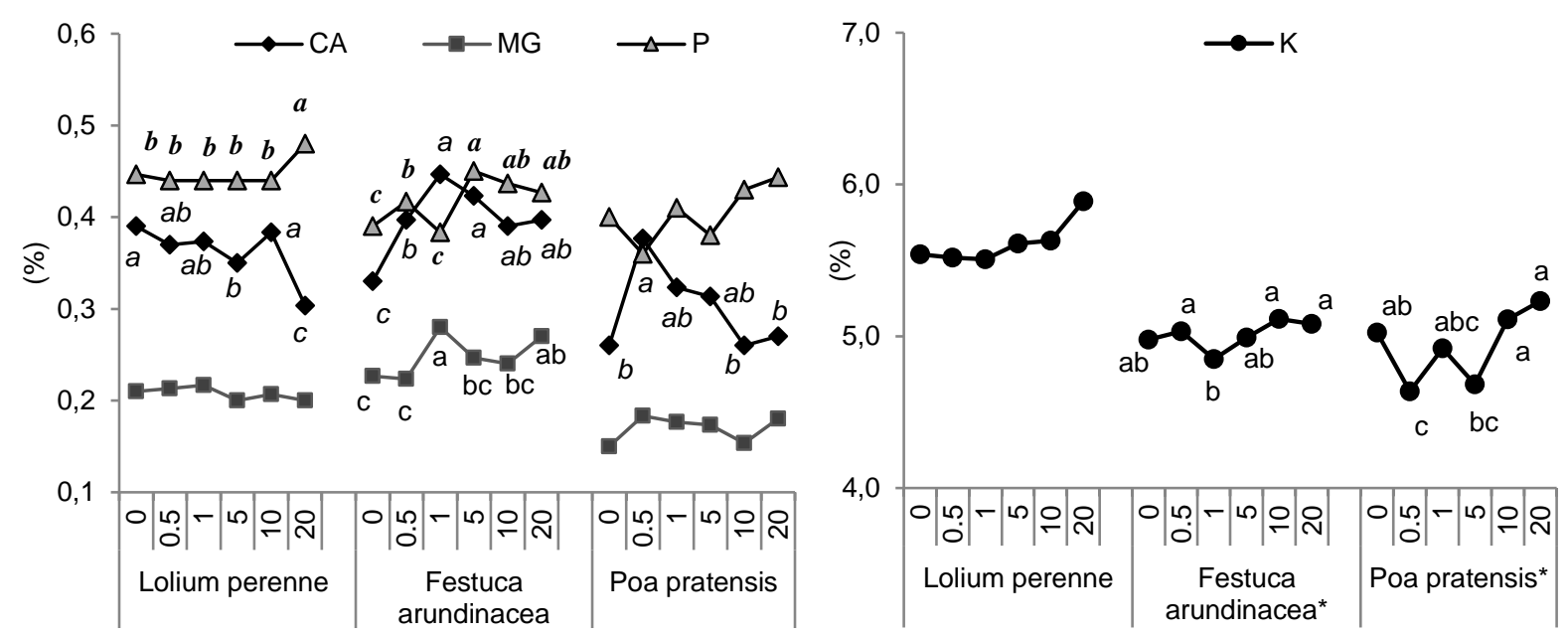

Figure 6. The main effect of smoke solution concentrations (\%) on mineral content (\%) of shoot in the studied turfgrasses in pot condition.*: $\mathrm{p} \leq 0.05$ for $\mathrm{P}$ in Lolium perenne, $\mathrm{Mg}$ in Festuca arundinacea and $\mathrm{Ca}$ in Poa pratensis, $\mathrm{K}$ in $\mathrm{Fa}$ and $P p^{* *}$ : $\mathrm{p} \leq 0.01$ for $\mathrm{Ca}$ in Lolium perenne and for $\mathrm{Ca}$ and $\mathrm{P}$ in Festuca arundinacea.

Compared with the control, it did not promote the Ca content in $L p$ and further reduced at the $5 \%$ and $20 \%$ concentrations. The stimulating effect of SS on Ca content was detected at all concentrations in $\mathrm{Fa}$ while at medium concentrations $(0.5 \%, 1 \%$ and $5 \%)$ in $P p$. The effect of SS on the $\mathrm{Mg}$ content was significant $(\mathrm{p} \leq 0.05)$ only in $F a$, with the highest value at the $1 \%$ and $20 \%$ concentrations. In $F a$ and $P p$, it resulted in a significant change in $\mathrm{K}$ content, but not statistically above control. The $\mathrm{K}$ content was lower than the control at the $1 \%$ doses in $F a$ and $0.5 \%$ and $5 \%$ in $P p$ (Figure 6).

\section{Discussion and Conclusion}

Under petri conditions, the effect of SS on the germination speed and percentage of $L p, F a$ and $P p$ was significant but not positive. Different results have been achieved in previous studies depending on the species studied, the plant used in the preparation of the smoke solution and the concentration of the solution (Elsadek \& Yousef, 2019). It was reported that smoke solution improved seed germination at low concentrations while it inhibited at high concentrations (Light et al., 2002; Chumpookam et al., 2012; Basaran et al., 2019; Gupta et al., 2020). The negative impact of SS in this study suggests that the concentrations examined may be high.

The results in pot experiment showed that the effect of the SS on the shoot and root length shoot and root dry weight, crude protein and mineral matters $(\mathrm{Ca}, \mathrm{Mg}, \mathrm{K}, \mathrm{P})$ is extremely complex and species-specific. Additionally, these differences can be related to the source of SS (wheat straw) or concentrations. Stimulating effect of SS on germination and seedling growth changed depend on the plant species used to prepare of solution (Elsadek \& Yousef, 2019). Ghebrehiwot et al. (2012) reported that SS at $0.02 \%$ resulted significantly longer shoots or roots than control in six dominate species grown South African mesic grassland, but the degree of response varied from species to species. Also, Adkins \& Peters (2001) found that the optimal concentration of SS were different for promoting the germination of Avena fatua and Malvane glecta. It is reported that aerosol smoke treatment at different periods (1, 2, 3 and $4 \mathrm{~h})$ significantly improved root length (2.6\%), shoot length $(7.7 \%)$ and leaf area $(63.9 \%)$ in four wheat cultivars, and this effect was observed in short time exposures $(1-2 \mathrm{~h})$ and varied amongst cultivars (Iqbal et al., 2017). In addition, positive effects were determined at low concentrations and toxic effects of high concentrations were reported almost in all the studies on smoke solutions. Promotive effect of SS was also demonstrated on the root length of soybean treated with 2000 ppm within 4 days (Zhong et al., 2020). It has been previously reported that SS (at 1, 5, 10, $20,40 \%$ concentrations) differently effected shoot and root dry weight in grass pea (Lathyrus sativus 
L.); shoot dry weight was stimulated notably at moderate concentrations (5\% and 10\%), but root dry weight was lower than control and also decreased in parallel to the concentrations (Basaran et al., 2019). It was also reported by Aslam et al. (2015) that SS obtained from different plants promoted shoot and root mass in wheat at very low concentrations $(<0.001 \%)$.

The positive effect of SS on shoot protein content was valid even at high concentrations depends on species. Similar findings were declared by Basaran et al. (2019). Proteomic analysis on 4day-old maize revealed that exposing $2000 \mathrm{ppm}$ of SS lead significant variation in the presence of 69 proteins (Aslam et al., 2019). The increase in protein content with the SS also reported in maize seedling by Waheed et al. (2016) and attributed to the advance in chlorophyll content. The stimulating effect of SS on the mineral-nutrient status has been reported by different authors. Elsadek \& Yousef (2019) who investigated the effects of SS derived from five different plants on mineral content in four crops reported that it contributed significantly to N, P, and K uptake depending on the species. Also, the nitrogen and magnesium content in the shoots were significantly improved with SS in papaya seedlings, but other minerals ( $\mathrm{P}, \mathrm{K}, \mathrm{Ca}, \mathrm{Fe}, \mathrm{Zn}, \mathrm{Mn}$, and $\mathrm{Cu}$ ) were similar to control (Chumpookam et al., 2012). Similarly, priming with SS increased the level of $\mathrm{K}, \mathrm{Ca}, \mathrm{N}$ and protein content in maize seedling while decrease $\mathrm{Na}$ content, and also alleviated the negative effect of salt stress (Waheed et al., 2016).

The results revealed that SS has a negative impact on germination in petri dishes but it has stimulated seedling growth in pot conditions in different degrees depending on the species or concentration.

SS have different stimulative effects on root, shoot grow and mineral uptake in each species. High concentrations did not have as much negative impact on protein and mineral content as on other properties, even caused better results. In addition, no visual or physiological problems were observed on plants in pot conditions at high concentrations. This indicates that high concentration increase mineral uptake and protein synthesis but not support vegetative growth too much. In addition, the effect of dense solutions may decrease in soil due to chemical or physical reasons. Therefore, suitable applications of smoke solution may lead to healthy, stress-resistant and vigorous seedlings even under lower fertilization. This is point out exciting economic and ecological advantages in turfgrass culture but that may be possible with new studies that are specific to species or even to characteristics.

\section{References}

Adkins,W., \& Peters, N. C. B. (2001). Smoke derived from burnt vegetation stimulates germination of arable weeds, Seed Science Research, 11, 213-222. doi: 10.1079/SSR200177.

Aslam, M. M., Jamil, M., Khatoon, A., El-Hendawy, S.E., AlSuhaibani, N.A., Shakirullah, S.S., Malook, I., \& Rehman, S. (2015). Does weeds-derived smoke improve plant growth of wheat, Journal Bio-Molecular. Science, 3, 86-96.

Aslam, M. M., Rehman, S., Khatoon, A., Jamil, M., Yamaguchi, H., Hitachi, K., Tsuchida, K., Li, X., Sunohara, Y., Matsumoto, H., \&Komatsu, S. (2019). Molecular Responses of Maize Shoot to a Plant Derived Smoke Solution, International Journal of Molecular Sciences, 20(6), 1319. doi:10.3390/ijms20061319.

Basaran, U., Copur Dogrusoz, M., Gulumser, E., \& Mut, H. (2019). Using smoke solutions in grass pea (Lathyrus sativus L.) to improve germination and seedling growth and reduce toxic compound ODAP, Turkish Journal of Agriciculture Forest, 43, 518-526. doi:10.3906/tar1809-66.

Baskin, C. C., \& Baskin, J. M. (1998). Seeds: Ecology, Biogeography and Evolution of Dormancy and Germination, Academic Press, San Diego. 273. doi:10.1006/anbo.2000.1238.

Chumpookam J., Lin, H., \& Shiesh, C. (2012). Effect of smoke-water on seed germination and seedling growth of Papaya (Carica papaya cv. tainung no.2), Horticultural Science, 47, 741744. doi: 10.21273/HORTSCI.47.6.741.

Clarke, S., \& French, K. (2005). Germination response to heat and smoke of 22 Poaceae species from grassy woodlands, Australian Journal of Botany 53, 445-454. DOI: 10.1071/BT04017.

Crosti, R., Ladd, P., Dixon, K., \& Piotto, B. (2006). Post-fire germination: the effect of smoke on seeds of selected species from the central Mediterranean basin, Forage Ecololgy Management, 221, 306-312.d:10.1016/j.foreco.2005.10.005. 
Dixon, K. W., Roche, S., \& Pate, J. S. (1995). The promotive effect of smoke derived from burnt native vegetation on seed germination of Western Australian plants, Oecologia, 101, 185-192. doi:10.1007/BF00317282.

Elsadek, A. M., \& Yousef, E. A. A. (2019). Smoke-Water Enhances Germination and Seedling Growth of Four, Horticultural Crops, 8, 104; doi:10.3390/plants8040104.

Ghebrehiwot, H. M., Kulkarni, G. M., Kirkman, K. P., \& Van Staden, J. (2009). Smoke solutions and temperature influence the germination and seedling growth of South African mesic grassland species, Rangeland Ecol Management., 62, 572-578. doi:10.2111/08-246.1.

Ghebrehiwot, H. M., Kulkarni, G. M., Kirkman, K. P., \& Van Staden, J. (2012). Smoke and heat: influence on seedling emergence from the germinable soil seed bank of mesic grassland in South Africa, Plant Growth Regulation, 66,119-127. doi: 10.1007/s10725-011-9635-5.

Gupta, S., Hrdlicka, J., Ngoroyemoto, N., Nemahunguni, N. K., Gucky, T., Novak, O., Kulkarni, M. J., Dolezal, K. \& Van Staden, J., (2020). Preparation and Standardisation of Smoke-Water for Seed Germination and Plant Growth Stimulation, Journal Plant Growth Regulation, 39, 338 345. doi:10.1007/s00344-019-09985-y.

Iqbal, M., Asif, S., Ilyas, N., Fayyaz-Ul-Hassan., Raja, N. I., Hussain, M., Ejaz, M., \& Saira, H. (2017). Smoke produced from plants waste material elicits growth of wheat (Triticum aestivum L.) by improving morphological, physiological and biochemical activity, Biotechnology reports, 17, 35-44. doi: 10.1016/j.btre.2017.12.001.

Jeffrey, D. J., Holmes, P.M., \& Rebelo, A.G. (1988). Effects of dry heat on seed germination in selected indigenous and alien legume species in South Africa, South African Journal of Botan, 54, 28-34. doi:10.1016/S0254-6299(16)31358-8.

Krol, P., Adamska, J., \& Kępczyska, E. (2014). Enhancement of Festucarubra L. germination and seedling growth by seed treatment with pathogenic Agrobacterium rhizogenes, ActaPhysiol Plant, 36, 3263-3274. doi:10.1007/s11738-014-1692-8.

Kulkarni, M. G., Light, M. E., \& Van Staden, J. (2011). Plant-derived smoke: old technology with possibilities for economic applications in agriculture and horticulture, South African Journal of Botanic. 77, 972-979, doi: 10.1016/j.sajb.2011.08.006.

Light, M. E., Gardner, M. J., Jager, A. K., \& Van Staden, J. (2002). Dual regulation of seed germination by smoke solutions, Plant Growth Regulation., 37, 135-141. doi:10.1023/A:1020536711989.

Read, T. R., \& Bellairs, S. M. (1999). Smoke affects the Germination of Native Grasses of New South Wales, Australian Journal of Botany, 47, 563-576. doi: 10.1071/BT97124.

Richardson, M. D. \& Hignight, K.W. (2010). Seedling emergence of tall fescue and kentucky bluegrass, as affected by two seed coating techniques, Hort Technology, 20, 415417. doi:10.21273/HORTTECH.20.2.415.

Salehi, H., \& Khosh-Khu1, M. (2005). Effects of genotype and plant growth regulator on callus induction and plant regeneration in four important turfgrass genera: a comparative study, In In Vitro Cellular \& Developmental Biology - Plant, 41, 157-161. doi:10.1079/IVP2004614.

Shiade, S. R. G., \& Boelt, B. (2020). Seed germination and seedling growth parameters in nine tall fescue varieties under salinity stress, Acta Agriculturae Scandinavica, Section B Soil \& Plant Science, 70 (6), 485-494. doi:10.1080/09064710.2020.1779338.

Sparg, S.G., Kulkarni, M.G., \& Van Staden, J. (2006). Aerosol smoke and smoke-water stimulation of seedling vigor of a commercial maize cultivar. Crop Science, 46, 1336-1340. doi:10.2135/cropsci2005.07-0324.

Van Staden, J., Brown, N. A. C., Jäger, A. K., \& Johnson, T. A. (2000). Smoke as a germination cue, Plant Species Biology, 15, 167-178. doi:10.1046/j.1442-1984.2000.00037.x.

Waheed, M. A., Muhammad, J., Muhammad, D. K., Shakirullah, K. S., \& UrRehman, S. (2016). Effect of plant-derived smoke solutions on physiological and biochemical attributes of maize (Zea mays L.) under salt stress, Pak Journal Botanica., 48, 1763-1774.

Zhong, Z., Kobayashi T., Zhu, W., Imai H., Rongyi, Z., Ohno, T., Shafiq ur Rehman, Uemura M., Tian J., \& Komatsu, S. (2020). Plant-derived smoke enhances plant growth through ornithinesynthesis pathway and ubiquitin-proteasome pathway in soybean, Journal of Proteomics. 221103781. doi: 10.1016/j.jprot.2020.103781. 